\title{
BENTUK TANGGUNG JAWAB NEGARA MENGHADAPI COVID-19 \\ DALAM PERSPEKTIF OTONOMI DAERAH \\ (Telaah Peraturan Pemerintah Nomor 21 Tahun 2020 tentang Pembatasan Sosial Berskala Besar)
}

\author{
${ }^{1}$ Haqkida Kancana, ${ }^{2}$ Dauri, ${ }^{3}$ Ummi Rahmatinnur, ${ }^{4}$ Nadya Waliyyatun Nisa, \\ ${ }^{5}$ Retias Dewi J. \\ ${ }^{1}$ Mahasiswa Magister Hukum Universitas Lampung \\ ${ }^{2}$ Asisten Peneliti Pusat Kajian Kebijakan Publik dan HAM \\ ${ }^{3}$ Staf Dinas Sosial Lampung \\ ${ }^{4}$ Pengajar Yayasan El-Qurro Kota Bumi Lampung \\ ${ }^{5}$ Staf Hukum Rumah Sakit Abdoel Moeloek Lampung \\ Jl. Soemantri Brojonogoro, No.1, Fakultas Hukum Universitas Lampung \\ Bandar Lampung \\ 0823-7323-8326 \\ haqkidakancana@gmail.com, dauri170996@gmail.com
}

\begin{abstract}
ABSTRAK: Penelitian ini bertujuan untuk melihat tanggungjawab negara dalam melindungi warga negara Indonesia yang terdampak maupun yang sudah dinyatakan positif covid-19 sesuai dengan UUD 1945 dan undang-undang kesehatan serta kebijakan penerapan Pembatasan Sosial Berskala Besar (PSBB) untuk masing-masing daerah. Metode yang digunakan yaitu Yuridis Normatif dan Yuridis Empiris, dengan cara menelaah dokumen dan peraturan perundang-undangan dan fakta yang terjadi pada masyarakat. Hasil penelitian ini menunjukkan bawa bentuk tanggng jawab negara dalam menghadapi Covid-19 ini yaitu melindungi warga negaranya dengan menerapkan PSBB yang dianggap dapat mengurangi penularan virus tersebut. Selain itu memberikan bantuan alat kesehatan, bantuan sembako kepada masyarakat agar dapat melangsungkan hidupan sehari-hari. Kesimpulannya adalah PSBB merupakan salah satu strategi pemerintah dalam mencegah kemungkinan penyebaran Covid-19.
\end{abstract}

KATA KUNCI: Tanggung jawab Negara, Covid-19, Otonomi Daerah.

ABSTRACT: This study aims to look at the state's responsibility in protecting Indonesian citizens who have been affected or who have tested positive for co-19 in accordance with the 1945 Constitution and the health law and the policy of implementing Large Scale Social Restrictions (Pembatasan Sosial Berskala Besar (PSBB)) for each region. The method used is Normative Juridical and Empirical Juridical, by examining documents and regulations and facts that occur in the community. The results of this study show that the responsibility of the state in dealing with Covid-19 is to protect its citizens by implementing PSBB which is considered to be able to reduce the transmission of the virus. In addition to providing medical aid assistance to food needs to the community so they can carry out daily life. The conclusion is the PSBB itself is one of the government's strategies in preventing the possibility of spreading the covid-19.

KEYWORDS: State Responsibility, Covid-19, Regional Autonomy 


\section{PENDAHULUAN}

Indonesia hukum memegang peran penting dalam berbagai segi kehidupan bermasyarakat dan bernegara. Salah satunya yaitu di bidang kesehatan, kesehatan merupakan hak asasi manusia dan salah satu unsur kesejahteraan yang harus diwujudkan sesuai dengan cita-cita bangsa Indonesia sebagaimana dimaksud dalam pancasila dan Undang-Undang Dasar Negara Republik Indonesia Tahun 1945. Dalam mewujudkan derajat kesehatan yang optimal bagi setiap orang, yang merupakan bagian dari kesejahteraan, diperlukan dukungan hukum bagi penyelenggaraan di bidang kesehatan. Hak atas derajat kesehatan yang optimal akan semakin kuat klaimnya jika dijustifikasi dengan jalan mengaitkannya dengan hak hidup, berhak atas hidup ekivalen dengan berhak atas derajat kesehatan yang optimal. ${ }^{1}$

Perekonomian dunia pada saat ini mengalami kehancuran yang sangat luar biasa, baik itu negara maju mapun negara berkembang. Hal tersebut di karenakan adanya wabah Virus Corona yang semakin hari semakin menambah korban yang terpapar, bahkan yang meninggal pada setiap negara. Selain itu, yang menjadi garda terdepan dalam menanganai kasus wabah virus corana ini adalah para medis, TNI/Polri dan pihak lian yang terlibat. Melaksanakan tugas tersebut bukan hal gampang, bahkan banyak tenaga medis yang tewas akibat membantu dalam penanganan wabah virus corana ini. Saat ini peran negara sangat di perlukan dalam mengabil sikap dan tanggungjawab terhadap penanganan Covid-19.

${ }^{1}$ El-Muthtaj, Majda, Hak Asasi Manusia dalam Konstitusi Indonesia, Jakarta: Kencana Prenada Media Group, 2009, hlm. 45.
Corona virus atau virus corona merupakan keluarga besar virus yang menyebabkan infeksi saluran pernapasan atas ringan hingga sedang, seperti penyakit flu. Banyak orang terinfeksi virus tersebut, setidaknya satu kali dalam hidupnya. Namun, beberapa jenis virus corona juga bisa menimbulkan penyakit yang lebih serius, seperti Middle East Respiratory Syndrome (MERSCoV), Severe Acute Respiratory Syndrome (SARS-CoV) dan Pneumonia. Penyakit ini adalah penyakit menular yang disebabkan oleh virus corona yang baru-baru ini ditemukan. Sebagian besar orang yang tertular Covid-19 akan mengalami gejala ringan hingga sedang dan akan pulih tanpa penanganan khusus.

Virus yang menyebabkan Covid-19 terutama ditransmisikan melalui droplet (tetesan kecil) yang dihasilkan saat orang yang terinfeksi batuk, bersin, atau mengembuskan nafas. Droplet ini terlalu berat sehingga tidak bisa bertahan di udara. Droplet dengan cepat jatuh dan menempel pada lantai atau permukaan lainnya. Infeksi Covid-19 kebanyakan melalui virus corona yang menyebar seperti virus lain pada umumnya, seperti Percikan air liur pengidap (bantuk dan bersin, menyentuh tangan atau wajah orang yang terinfeksi, menyentuh mata, hidung, atau mulut setelah memegang barang yang terkena percikan air liur pengidap virus corona, dan tinja atau feses (jarang terjadi).

Khusus untuk Covid-19, masa inkubasi belum diketahui secara pasti. Namun, rata-rata gejala yang timbul setelah 2-14 hari setelah virus pertama masuk ke dalam tubuh. ${ }^{2}$ Di samping itu, metode transmisi Covid-19 juga belum diketahui dengan pasti. Awalnya, virus

2 Mile Parwanto, Virus Corona (2019nCoV) Penyebab Covid-19, Jurnal Biomedika dan Kesehatan, Volume.3, Nomor,1, Maret, 2020, hlm. 1-2. 
corona jenis Covid-19 diduga bersumber dari hewan. Covid-19 merupakan virus yang beredar pada beberapa hewan, termasuk unta, kucing, dan kelelawar. Sebenarnya virus ini jarang sekali berevolusi dan menginfeksi manusia dan menyebar ke individu lainnya. Namun, kasus di Tiongkok kini menjadi bukti nyata kalau virus ini bisa menyebar dari hewan ke manusia. Bahkan, kini penularannya bisa dari manusia ke manusia.

World Health Organization (WHO) menetapkan wabah Covid-19 atau virus corona (SARS CoV-2) menjadi pandemi global. Peningkatan status ini diumumkan langsung oleh Direktur Jenderal WHO Tedros Ghebreyesus di Jenewa, Swiss pada 11 Maret 2020. Penetapan status pandemi ini disebabkan oleh penyebaran yang begitu cepat dan luas hingga ke wilayah yang jauh dari pusat wabah. ${ }^{3}$

Presiden Joko Widodo secara resmi menetapkan wabah virus corona Covid19 sebagai bencana nasional. Penetapan ini dilakukan lewat penerbitan Keputusan Presiden Nomor 12 Tahun 2020 tentang Penetapan Bencana Non alam Penyebaran Corona Virus Disease 2019 (Covid-19) sebagai bencana nasional. ${ }^{4}$ Kasus positif Covid-19 menyebar di Indonesia pertama kali pada 2 Maret 2020, ketika seorang instruktur dansa dan ibunya terkonfirmasi tertular dari seorang warga negara Jepang. Pada 31 Mei 2020, Indonesia telah melaporkan total kasus

\footnotetext{
${ }^{3}$ World Health Organization Press

Conference

(https://www.who.int/emergencies/diseases/nove 1 -

coronavirus2019?gclid=CjwKCAjwq832BRA5E iwACvCWsbpLiaNmFMJRaG905w1XqiiOfpgU kZ_PMEfS_W-

xqpaEW93J3snu8xoClXcQAvD_BwE) Diakses pada minggu tanggal 31 Mei 2020 pukul 20.52 WIB

${ }^{4}$ Keputusan Presiden RI Nomor 12

Tahun 2020 tentang Penetapan bencana non alam
}

positif 26.473 kasus, sembuh 7.308 kasus, dan meninggal 1.613 kasus yang sudah menyebar ke 34 provinsi dan sudah 416 kabupaten dan kota yang terdampak dengan DKI Jakarta, Jawa Barat, dan Jawa Timur sebagai provinsi paling terpapar, sehingga menempati peringkat kedua terbanyak di Asia Tenggara setelah Singapuran dan sebelum Filipina. ${ }^{5}$

Pemerintah Indonesia telah menguji 323.376 sampel dari 273,2 juta penduduk, yang berarti hanya sekitar 1.184 pengujian per satu juta penduduk, menjadikannya salah satu negara dengan jumlah rasio pengujian terendah di dunia. Sebagai perbandingan, rasio Indonesia lebih rendah daripada Kamboja yang hanya berpenduduk 16,7 juta jiwa tapi memiliki rasio pengujian 1.222 per satu juta penduduk. $^{6}$

Hak atas kesehatan juga dapat ditemukan di instrumen nasional di dalam pasal $28 \mathrm{H}$ ayat (1) dan pasal 34 ayat (3) amandemen UUD 1945, Pasal 9 UU No. 39 tahun 1999 tentang Hak Asasi Manusia dan pasal 12 UU No. 11 Tahun 2005 tentang Pengesahan Kovenan Hak Ekonomi Sosial, dan Budaya. Ketentuan dalam UUD 1945 diatas lebih lanjut diatur di dalam UU No. 36 Tahun 2009 tentang Kesehatan. Dalam pasal 9 ayat (1) UU Kesehatan dinyatakan, bahwa "Setiap orang berkewajiban ikut mewujudkan, mempertahankan, dan meningkatkan derajat kesehatan masyarakat yang setinggi-tingginya". Ayat (2) menegaskan, bahwa "Kewajiban

penyebaran Covid-19 sebagai bencana nasional https://jdih.setneg.go.id/viewpdfperaturan/P1885 7/Keppres\%20Nomor\%2012\%20Tahun\%202020 Diakses pada minggu tanggal 31 Mei 2020 pukul 20.58 WIB

${ }^{5}$ Data Sebaran Situasi virus Covid-19 di Indonesia https://covid19.go.id/ Diakses minggu tanggal 31 Mei 2020 pada 21.01 WIB

${ }^{6}$ Data Sebaran Situasi virus Covid-19 di Indonesia https://covid19.go.id/ Diakses minggu tanggal 31 Mei 2020 pada 21.01 WIB 
sebagaimana dimaksud pada ayat (1), pelaksanaannya meliputi upaya kesehatan perseorangan, upaya kesehatan masyarakat, dan pembangunan berwawasan kesehatan".

Dalam rangka percepatan penanganan pandemi Covid-19 beberapa wilayah telah memberlakukan pembatasan sosial berskala besar (PSBB) sesuai dengan Peraturan Pemerintah Nomor 21 Tahun 2020 tentang Pembatasan Sosial Berskala Besar. Adanya PP mengenai PSBB memberikan kesempatan pada daerah untuk melakukan berbagai pertimbangan (Pasal 2) dan kemudian mengajukan PSBB kepada Menteri Kesehatan. Pemberlakuan dan penerapan PSBB memang bersifat sentralistis. Meski demikian, bukan berarti menutup ruang kreatif daerah. Undang-Undang Nomor 23 tahun 2014 tentang Pemerintahan Daerah memberi cukup ruang bagi daerah dalam penanganan pandemi (sebagai bencana atau keadaan luar biasa). Permasalahan dalam penelitian ini adalah bagaimanakah bentuk tanggungjawab negara menghadai Covid-19 dalam perspektif otonomi daerah.

\section{METODE}

Metode yang digunakan dalam penelitian ini adalah yuridis normatif dan yuridis empiris. ${ }^{7}$ Metode yang digunakan tersebut dalam pelaksanaan penelitian dikakukan dengan mengkolaborasikan dalam bentuk pertanyaan dan fakta lapangan. Pendekatan masalah yang digunakan dalam penelitian ini dengan cara normatif. Suatu penelitian Yuridus normatif adalah pendekatan yang dilakukan berdasarkan bahan hukum utama, menelaah hal-hal yang bersifat teoritis yang menyangkut asas-asas

7 Abdul Kadir Muhammad, Hukum dan Penelitian Hukum, Bandung: Citra Aditya Bakti, 2004, hlm 32. hukum, konsepsi hukum, pandangan dan doktrin-dotrin hukum, peraturan dan sistem hukum. ${ }^{8}$ Penelitian Yuridus empiris dilakukan dengan menelaah fakta yang terjadi di lapangan, kemudian di koloborasikan dengan peraturan perundang-undangan sesuai dengan bentuk tanggungjawab negara menghadapi covid-19 dalam perspektif otonomi daerah.

\section{HASIL DAN PEMBAHASAN}

\section{Pandemi Covid-19}

Virus Corona atau severe acute respiratory syndrome coronavirus 2 (SARS-CoV-2) adalah virus yang menyerang sistem pernapasan. Penyakit karena infeksi virus ini disebut Covid-19. Virus Corona bisa menyebabkan gangguan ringan pada sistem pernapasan, infeksi paru-paru yang berat, hingga kematian. Severe acute respiratory syndrome coronavirus 2 (SARS-CoV-2) yang lebih dikenal dengan nama virus Corona adalah jenis baru dari coronavirus yang menular ke manusia. Walaupun lebih banyak menyerang lansia, virus ini sebenarnya bisa menyerang siapa saja, mulai dari bayi, anak-anak, hingga orang dewasa, termasuk ibu hamil dan ibu menyusui.

Infeksi virus Corona disebut Covid-19 (Corona Virus Disease 2019) dan pertama kali ditemukan di kota Wuhan, China pada akhir Desember 2019. Virus ini menular dengan sangat cepat dan telah menyebar ke hampir semua negara, termasuk Indonesia, hanya dalam waktu beberapa bulan. Hal tersebut membuat beberapa negara menerapkan kebijakan untuk memberlakukan lockdown dalam rangka mencegah penyebaran virus Corona. Di Indonesia sendiri, diberlakukan kebijakan Pembatasan Sosial Berskala Besar

8 Soerjono Soekanto, Penelitian Hukum, Jakarta: Rajawali Press, 2004, hlm. 10. 
(PSBB) untuk menekan penyebaran virus ini.

Coronavirus adalah kumpulan virus yang bisa menginfeksi sistem pernapasan. Pada banyak kasus, virus ini hanya menyebabkan infeksi pernapasan ringan, seperti flu. Namun, virus ini juga bisa menyebabkan infeksi pernapasan berat, seperti infeksi paru-paru (pneumonia). Selain virus SARS-CoV-2 atau virus Corona, virus yang juga termasuk dalam kelompok ini adalah virus penyebab Severe Acute Respiratory Syndrome (SARS) dan virus penyebab Middle-East Respiratory Syndrome (MERS). Meski disebabkan oleh virus dari kelompok yang sama, yaitu coronavirus, Covid-19 memiliki beberapa perbedaan dengan SARS dan MERS, antara lain dalam hal kecepatan penyebaran dan keparahan gejala.

a. Penyebab Virus Corona (Covid-19)

Infeksi virus Corona atau Covid-19 disebabkan oleh coronavirus, yaitu kelompok virus yang menginfeksi sistem pernapasan. Pada sebagian besar kasus, coronavirus hanya menyebabkan infeksi pernapasan ringan sampai sedang, seperti flu. Akan tetapi, virus ini juga bisa menyebabkan infeksi pernapasan berat, seperti pneumonia, Middle-East Respiratory Syndrome (MERS) dan Severe Acute Respiratory Syndrome (SARS). Ada dugaan bahwa virus Corona awalnya ditularkan dari hewan ke manusia. Namun, kemudian diketahui bahwa virus Corona juga menular dari manusia ke manusia.

Seseorang dapat tertular Covid-19 melalui berbagai cara, yaitu:

1) Tidak sengaja menghirup percikan ludah (droplet) yang keluar saat penderita Covid-19 batuk atau bersin.

2) Memegang mulut atau hidung tanpa mencuci tangan terlebih dulu setelah

9 Eman Supriatna, Wabah Corona Virus Diasea Covid 19 dalam Pandangan Islam, SALAM: JUrnal Sosial dan BUdaya Syar'I, menyentuh benda yang terkena cipratan ludah penderita Covid-19.

3) Kontak jarak dekat dengan penderita Covid-19

Virus Corona dapat menginfeksi siapa saja, tetapi efeknya akan lebih berbahaya atau bahkan fatal bila terjadi pada orang lanjut usia, ibu hamil, orang yang memiliki penyakit tertentu, perokok, atau orang yang daya tahan tubuhnya lemah, misalnya pada penderita kanker. Karena mudah menular, virus ini juga berisiko tinggi menginfeksi para tenaga medis yang merawat pasien Covid-19. ${ }^{9}$ Oleh karena itu, para tenaga medis dan orang-orang yang memiliki kontak dengan pasien Covid-19 perlu menggunakan alat pelindung diri (APD).

\section{b. Gejala Virus Corona (Covid-19)}

Gejala awal infeksi virus Corona atau Covid-19 bisa menyerupai gejala flu, yaitu demam, pilek, batuk kering, sakit tenggorokan, dan sakit kepala. Setelah itu, gejala dapat hilang dan sembuh atau malah memberat. Penderita dengan gejala yang berat bisa mengalami demam tinggi, batuk berdahak bahkan berdarah, sesak napas, dan nyeri dada. Gejala-gejala tersebut muncul ketika tubuh bereaksi melawan virus Corona.

Secara umum, ada 3 gejala umum yang bisa menandakan seseorang terinfeksi Covid-19, yaitu:

1) Demam (Suhu tubuh di atas $38^{\circ} \mathrm{C}$ )

2) Batuk kering

3) Sesak napas

Ada beberapa gejala lain yang juga bisa muncul pada infeksi Covid-19 meskipun lebih jarang, yaitu:

1) Diare

2) Sakit kepala

3) Konjungtivitis

Volume.7, NOmor.6 Tahun 2020, hlm. 555-567, DOI: $10.15408 /$ sjsbs.v7i6.15247 
4) Hilangnya kemampuan mengecap rasa atau mencium bau

5) Ruam di kulit

Gejala umumnya muncul dalam waktu 2 hari sampai 2 minggu setelah penderita terpapar Covid-19.

c. Diagnosis Virus Corona (Covid-19)

Untuk menentukan apakah pasien terinfeksi virus Corona, dokter akan menanyakan gejala yang dialami pasien dan apakah pasien baru saja bepergian atau tinggal di daerah yang memiliki kasus infeksi virus Corona sebelum gejala muncul. Dokter juga akan menanyakan apakah pasien ada kontak dengan orang yang menderita atau diduga menderita Covid-19.

Guna memastikan diagnosis Covid19, dokter akan melakukan beberapa pemeriksaan berikut:

a) Rapid test untuk mendeteksi antibodi (IgM dan IgG) yang diproduksi oleh tubuh untuk melawan virus Corona

b) Swab test atau tes PCR (polymerase chain reaction) untuk mendeteksi virus Corona di dalam dahak

c) CT scan atau Rontgen dada untuk mendeteksi infiltrat atau cairan di paru-paru

Hasil rapid test Covid-19 positif kemungkinan besar menunjukkan bahwa Anda memang sudah terinfeksi virus Corona, namun bisa juga berarti Anda terinfeksi kuman atau virus yang lain. Sebaliknya, hasil rapid test Covid-19 negatif belum tentu menandakan bahwa Anda mutlak terbebas dari virus Corona.

\section{d) Pengobatan Virus Corona (Covid-19)}

Infeksi virus Corona atau Covid-19 belum bisa diobati, tetapi ada beberapa langkah yang dapat dilakukan dokter untuk meredakan gejalanya dan mencegah penyebaran virus, yaitu:

1) Merujuk penderita Covid-19 yang berat untuk menjalani perawatan dan karatina di rumah sakit rujukan
2) Memberikan obat pereda demam dan nyeri yang aman dan sesuai kondisi penderita

3) Menganjurkan penderita Covid-19 untuk melakukan isolasi mandiri dan istirahat yang cukup

4) Menganjurkan penderita Covid-19 untuk banyak minum air putih untuk menjaga kadar cairan tubuh

e) Komplikasi Virus Corona (Covid-19) Pada kasus yang parah, infeksi virus Corona bisa menyebabkan beberapa komplikasi berikut ini:

1) Pneumonia (infeksi paru-paru)

2) Infeksi sekunder pada organ lain

3) Gagal ginjal

4) Acute cardiac injury

5) Acute respiratory distress syndrome

6) Kematian

f) Pencegahan Virus Corona (Covid-19) Sampai saat ini, belum ada vaksin untuk mencegah infeksi virus Corona atau Covid-19. Oleh sebab itu, cara pencegahan yang terbaik adalah dengan menghindari faktor-faktor yang bisa menyebabkan Anda terinfeksi virus ini, yaitu:

1) Terapkan physical distancing, yaitu menjaga jarak minimal 1 meter dari orang lain, dan jangan dulu ke luar rumah kecuali ada keperluan mendesak.

2) Gunakan masker saat beraktivitas di tempat umum atau keramaian, termasuk saat pergi berbelanja bahan makanan.

3) Rutin mencuci tangan dengan air dan sabun atau hand sanitizer yang mengandung alkohol minimal $60 \%$, terutama setelah beraktivitas di luar rumah atau di tempat umum.

4) Jangan menyentuh mata, mulut, dan hidung sebelum mencuci tangan.

5) Tingkatkan daya tahan tubuh dengan pola hidup sehat, seperti mengonsumsi makanan bergizi, 
berolahraga secara rutin, beristirahat yang cukup, dan mencegah stres.

6) Hindari kontak dengan penderita Covid-19, orang yang dicurigai positif terinfeksi virus Corona, atau orang yang sedang sakit demam, batuk, atau pilek.

7) Tutup mulut dan hidung dengan tisu saat batuk atau bersin, kemudian buang tisu ke tempat sampah.

8) Jaga kebersihan benda yang sering disentuh dan kebersihan lingkungan, termasuk kebersihan rumah.

Untuk orang yang diduga terkena Covid-19 atau termasuk kategori ODP (orang dalam pemantauan) maupun PDP (pasien dalam pengawasan), ada beberapa langkah yang bisa dilakukan agar virus Corona tidak menular ke orang lain, yaitu:

1) Lakukan isolasi mandiri dengan cara tinggal terpisah dari orang lain untuk sementara waktu. Bila tidak memungkinkan, gunakan kamar tidur dan kamar mandi yang berbeda dengan yang digunakan orang lain.

2) Jangan keluar rumah, kecuali untuk mendapatkan pengobatan.

3) Bila ingin ke rumah sakit saat gejala bertambah berat, sebaiknya hubungi dulu pihak rumah sakit untuk menjemput.

4) Larang orang lain untuk mengunjungi atau menjenguk Anda sampai Anda benar-benar sembuh.

5) Sebisa mungkin jangan melakukan pertemuan dengan orang yang sedang sedang sakit.

6) Hindari berbagi penggunaan alat makan dan minum, alat mandi, serta perlengkapan tidur dengan orang lain.

7) Pakai masker dan sarung tangan bila sedang berada di tempat umum atau sedang bersama orang lain.

10 Budi Andriyansayah, Hak Atas Kesehatan dan Perlindungannya, Jurnal Ilmu
8) Gunakan tisu untuk menutup mulut dan hidung bila batuk atau bersin, lalu segera buang tisu ke tempat sampah.

Kondisi-kondisi yang memerlukan penanganan langsung oleh dokter di rumah sakit, seperti melahirkan, operasi, cuci darah, atau vaksinasi anak, perlu ditangani secara berbeda dengan beberapa penyesuaian selama pandemi Covid-19. Tujuannya adalah untuk mencegah penularan virus Corona selama Anda berada di rumah sakit. Konsultasikan dengan dokter mengenai tindakan terbaik yang perlu dilakukan.

\section{Bentuk Tanggungjawab Negara Dalam Penanganan Covid-19}

Hak atas kesehatan juga dapat ditemukan di instrumen nasional di dalam pasal $28 \mathrm{H}$ ayat (1) dan pasal 34 ayat (3) amandemen UUD 1945, pasal 9 UU No. 39 tahun 1999 tentang Hak Asasi Manusia dan pasal 12 UU No. 11 Tahun 2005 tentang Pengesahan Kovenan Hak Ekonomi Sosial, dan Budaya. Ketentuan dalam UUD 1945 diatas lebih lanjut diatur di dalam UU No. 36 Tahun 2009 tentang Kesehatan. Hak atas kesehatan memiliki aspek ekonomi, sosial, dan budaya. Hak ini memiliki karakter ekonomi dan sosial karena hak ini berusaha sedapat mungkin menjaga agar individu tidak menderita ketidakadilan sosial dan ekonomi berkenaan dengan kesehatannya. Lebih lanjut, hak ini memiliki karakter budaya sebab hak ini berusaha menjaga agar layanan kesehatan yang tersedia cukup dapat menyesuaikan dengan latar belakang budaya seseorang. ${ }^{10}$

Hak atas kesehatan dalam hubungan dengan kategori hak asasi manusia, sering dimasukkan dalam hak asasi manusia generasi kedua dan hak

Hukum, Volume. 1, Nomor.2, September, 2017, hlm. 123-135. 
asasi manusia generasi ketiga. Kegelisahan yang terjadi saat ini sebagai warganegara Indonesia yang memiliki legalitas dalam terjaminnya hak setiap masyarakat merupakan salah satu bentuk kepedulian dan tanggungjawab pemerintah Indonesia terhadap HAM. Dalam penanganan pandemi wabah Covid-19 ini, hak dari setiap warga negara harus dijamin, baik sebagai tenaga medis ataupun sebagai terdampak dari corona yang menyebabkan kematian. Kematian tersebut tidak hanya nyawa, namun juga kematian dari segi ekonomi, keamanan, dan ekpresi dari setiap warga masyarakat. Oleh karenanya dalam hal ini juga pemberian bantuan baik secara langsung dan tidak langsung dari pemerintah merupakan bentuk perlindungan terhadap kesehatan dari HAM tersebut.

Sementara itu, isi pokok (core content) hak atas kesehatan tidak hanya mencakup unsur-unsur yang berkaitan dengan hak atas pelayanan perawatan kesehatan, tetapi juga hak atas sejumlah prasyarat dasar bagi kesehatan, seperti air minum bersih, sanitasi memadai, kesehatan lingkungan, dan kesehatan di tempat kerja. Kemudian yang menjadi prinsip-prinsip yang harus ditaati oleh pihak negara dalam pemenuhan hak atas kesehatan mengandung empat unsur, yakni ketersediaan, aksesibilitas, kualitas, dan kesetaraan. Adanya Covid-19 ini negara seharus bisa lebih mementing hakhak yang dimilik oleh masyarakat akibat adanya kebijakan untuk tidak keluar rumah dan tetap bekerja dari rumah. Namun hal demikian tanggungjawab negara dalam penerapan fungsi dan memilihara hak dari setiap masyarakat seyogyanya dapat memberikan pasilitas yang memadai. Walapun hal yang terjadi saat ini merupakan takdir, akan tetapi tanggungjawab yang melekat harsu tetap di jalankan dan mempertimbangkan segala dampak yang akan di timbulkan apabila hal tersbut tidak dilakukan.

Sejak kesehatan diakui sebagai sebagai salah satu hak asasi manusia, dalam penerapannya terdapat berbagai pengertian. Hal tersebut tidak terlepas dari pengertian "kesehatan". Kesehatan menurut Undang-Undang Nomor 36 tahun 2009 Tentang Kesehatan adalah keadaan sehat, baik secara fisik, mental, spritual maupun sosial yang memungkinkan setiap prang untuk hidup produktif secara sosial dan ekonomis. Pengertian yang luas itu berpengaruh bagi pemahaman terhadap kesehatan sebagai hak asasi manusia. Dalam Pasal 4 Undang-undang kesehatan ditegaskan bahwa "Setiap orang berhak atas kesehatan", sedangkan Pasal $28 \mathrm{H}$ Undang-Undang Dasar 1945, menegaskan bahwa "Setiap orang berhak hidup sejahtera lahir dan batin, bertempat tinggal, dan mendapatkan lingkungan hidup yang baik dan sehat serta berhak memperoleh pelayanan kesehatan.

Dalam kepustakaan kesehatan, terdapat berbagai istilah yang digunakan untuk menyebut hak asasi manusia di bidang kesehatan, seperti "hak asasi atas kesehatan" (Human Right to Health), atau "hak atas kesehatan"(Right to Health), atau "hak memperoleh derajat kesehatan yang optimal" (The Right to Attainable Standard To Health). ${ }^{11}$ Hukum berkepentingan bukan pada istilah, melainkan pada makna yang terkandung dalam istilah tersebut. Apalagi setelah UUD 45 memberikan jaminan konstitusional terhadap hak atas kesehatan, mengenali hak tersebut secara benar menjadi sangat penting bagi hukum.

11 Muladi, Sumbang Saran Peruabahan UUD 1945, Jakarta: Yayasan Habibie Center, 2004, hlm. 16. 
Memuat ketentuan jaminan hak asasi manusia, termasuk hak atas kesehatan, ke dalam Undang-Undang Dasar 1945, sebagai sebuah komitmen politik Negara, hal ini mungkin telah menyelesaikan berbagai tuntutan politik dan harapan rakyat, tetapi dari perspektif hukum tata negara, hal tersebut masih mengandung persoalan. Persoalan utama terkait dengan beragamnya batasan atau definisi hak atas kesehatan, padahal batasan tersebut sangat penting bagi kepastian hukum. Tanpa batasan yang jelas, akan sulit menentukan ruang lingkup tanggung jawab negara sebagaimana yang ditegaskan dalam UUD 1945. Ketersediaan dapat diartikan sebagai ketersediaan sejumlah pelayanan kesehatan seperti fasilitas berupa sarana (rumah sakit, puskesmas dan klinik) dan prasarana kesehatan (obat-obatan, tenaga kesehatan dan pembiayaan kesehatan) yang mencukupi untuk penduduk secara keseluruhan dalam menghadapi Covid19.

Landasan utama bahwa perlindungan HAM merupakan kewajiban pemerintah adalah prinsip demokrasi bahwa sesungguhnya pemerintah diberi amanah kekuasaan adalah untuk melindungi hak-hak warga negara. Terlebih lagi dengan konsep negara kesejahteraan (welfare state) sebagai konsep negara modern telah memberikan kekuasaan lebih besar pada pemerintah untuk bertindak. Kekuasaan ini semata-mata adalah untuk memajukan dan mencapai pemenuhan hak asasi manusia. Pemerintah tidak lagi hanya menjaga agar seseorang tidak melanggar atau dilanggar haknya, namun harus mengupayakan pemenuhan hak-hak tersebut. Demikian pula dengan hak atas kesehatan, merupakan kewajiban pemerintah untuk memenuhinya. Dalam pasal 9 ayat (1) UU Kesehatan dinyatakan, bahwa "Setiap orang berkewajiban ikut mewujudkan, mempertahankan, dan meningkatkan derajat kesehatan masyarakat yang setinggi-tingginya". Ayat (2) menegaskan, bahwa "Kewajiban sebagaimana dimaksud pada ayat (1), pelaksanaannya meliputi upaya kesehatan perseorangan, upaya kesehatan masyarakat, dan pembangunan berwawasan kesehatan".

Seperti yang dikemukakan, kesehatan sebagai hak asasi manusia tidak terlepas dari ciri-ciri hak asasi manusia, yaitu "hak" dalam arti yang sesungguhnya dan bersifat prima facie. Kalaupun ada kewajiban yang melekat pada hak asasi manusia, hal itu sematamata sebagai pembatasan agar pelaksanaan hak asasi manusia tersebut tidak melanggar hak asasi orang lain. Apabila ketentuan Pasal 9 Undangundang tersebut dimaknai demikian, kenapa kewajiban itu tidak hanya ditujukan untuk memelihara kesehatan orang lain, tetapi juga kesehatan perseorangannya? Untuk menjelaskan hal ini penulis menggunakan contoh yang berkenaan dengan penaganan dan tanggungjawab negara dalam menangani Covid-19 yang sedang dihadapi Indonesia. Tanggungjawab ini adalah kewajiban yang harus dilaksanakan oleh pemerintah Indonesia dalam memberikan hak-hak terhadap masyarakat dan tenaga medis yang menjadi garda terdepan dalam penanganan Covid-19. Oleh karenanya bentuk tanggungjawab negara dapat berupa pemeunhan hak baik secara lahir maupun batin terhadap masyarakat Indoensia yang terdampak Covid-19.

\section{Pembatasan Sosial Berskala Besar (PSBB)}

Pandemi Covid-19 yang saat ini masih berlangsung di hampir seluruh negara di dunia, termasuk Indonesia, merupakan pandemi yang memiliki dampak global yang cukup besar. Seiring 
dengan semakin gencar-gencarnya strategi pemerintah dalam menanggulangi penyebaran Covid-19 yang masih mewabah hingga saat ini pemerintah mulai memberlakukan Pembatasan Sosial Berskala Besar (PSBB) yang dianggap mampu mempercepat penanggulangan sekaligus mencegah penyebaran corona yang semakin meluas di Indonesia. ${ }^{12}$ Pada 31 Maret 2020 lalu Presiden Joko Widodo (Jokowi) telah menandatangani Peraturan Pemerintah (PP) Nomor 21 Tahun 2020 tentang PSBB dalam rangka percepatan penanganan coronavirus disease (Covid-19).

Berdasarkan PP Nomor 21 Tahun 2020 Pasal 1, dijelaskan bahwa Pembatasan Sosial Berskala Besar merupakan pembatasan kegiatan tertentu dalam suatu wilayah yang diduga terinfeksi Coronavirus Disease 2019 (Covid-19). PSBB sendiri merupakan salah satu strategi pemerintah dalam mencegah kemungkinan penyebaran virus corona, yang mana juga telah tertuang di dalam aturan PMK Nomor 9 Tahun 2020.

Tertulis pula di dalam aturan PMK Nomor 9 Tahun 2020 pasal 2, bahwa untuk dapat ditetapkan sebagai PSBB, maka suatu wilayah provinsi/ kabupaten/ kota harus memenuhi dua kriteria. Pertama, yaitu jumlah kasus atau kematian akibat penyakit meningkat dan menyebar secara signifikan secara cepat ke beberapa wilayah.

Sementara kriteria kedua adalah bahwa wilayah yang terdapat penyakit juga memiliki kaitan epidemiologis dengan kejadian serupa yang terdapat di wilayah atau negara lain. Dari kedua kriteria itulah pada nantinya Menkes dapat menentukan apakah wilayah atau daerah tersebut layak untuk diterapkan PSBB atau tidak.

12 Silpa Hnoatubun, Dampak Covid-19 Tergadap Perekonomian Indonesia, Journal of
Namun, para kepala daerah juga memiliki hak untuk mengajukan permohonan PSBB yang didasari oleh data kasus Covid-19 yang terjadi di daerahnya masing-masing. Apabila suatu wilayah telah disetujui oleh Menkes, maka PSBB akan diberlakukan selama masa inkubasi terpanjang, yaitu 14 hari. Namun, apabila setelah 14 hari tersebut masih terlihat adanya penyebaran, seperti ditemukannya kasus baru, maka masa PSBB akan diperpanjang selama 14 hari kedepan hingga kasus terakhir ditemukan.

\section{a) Hal-hal yang dibatasi selama PSBB}

Dengan diterapkannya PSBB, khususnya di Ibu Kota Jakarta, diharapkan hal ini dapat mencegah sekaligus memperlambat penyebaran virus corona di seluruh wilayah di Indonesia. Berbeda dengan himbauan social distancing, PSBB dapat dikatakan menerapkan peraturan yang jauh lebih ketat untuk masyarakatnya. Terdapat beberapa hal yang dibatasi selama PSBB ini berlangsung, diantaranya adalah:

1. Aktivitas di Sekolah dan Tempat Kerja

Membatasi aktivitas sekolah dan tempat kerja masuk ke dalam hal yang harus diperhatikan selama PSBB berlangsung, kecuali kantor atau instansi strategi yang memberikan pelayanan ketahanan atau keamanan, ketertiban umum, kebutuhan pangan, bahan bakar minyak atau gas, kesehatan, perekonomian, keuangan, dan kebutuhan dasar lainnya.

\section{Kegiatan Keagamaan}

Masyarakat juga dihimbau untuk sementara waktu tidak melakukan aktivitas di luar rumah yang berkemungkinan untuk berkontak dengan sekumpulan orang dalam jumlah banyak. Selain itu, kegiatan keagamaan juga harus

Education, Psychology and Counseling, Volume 2, Nomor 1, Tahun 2020, hlm. 146-153. 
berpedoman pada peraturan perundangundangan serta fatwa atau pandangan lembaga keagamaan resmi yang diakui oleh pemerintah.

\section{Kegiatan di Tempat atau} Fasilitas Umum

Selama PSBB, kegiatan yang diselenggarakan di tempat atau fasilitas umum harus dilaksanakan dalam bentuk pembatasan jumlah orang dan pengaturan jarak atau physical distancing.

Namun, pembatasan ini tidak berlaku untuk supermarket, minimarket, pasar, toko, atau tempat penjualan obat dan peralatan medis, kebutuhan pangan, barang kebutuhan pokok, bahan bakar minyak dan gas serta energi.

Selain itu, fasilitas pelayanan kesehatan dan tempat kegiatan olahraga juga masuk ke dalam daftar yang dikecualikan.

4. Kegiatan Sosial dan Budaya

Sama halnya dengan kegiatan di tempat atau fasilitas umum, pembatasan kegiatan sosial dan budaya juga harus diadakan dalam bentuk pelarangan kerumunan orang. Larangan ini juga berpedoman pada pandangan lembaga adat resmi yang diakui pemerintah dan peraturan perundang-undangan.

5. Operasional Transportasi Umum

Selama masa PSBB, transportasi umum masih beroperasi seperti biasa. Hanya saja, pembatasan dilakukan dengan memperhatikan jumlah penumpang yang naik serta menjaga jarak antar penumpang. Tidak hanya itu, moda transportasi barang yang beroperasi untuk memenuhi kebutuhan dasar masyarakat juga dikecualikan.

\section{b) Fungsi PSBB di Indonesia}

Seiring dengan semakin meningkatnya jumlah orang yang terinfeksi virus corona Covid-19 di Indonesia, maka terhitung mulai dari hari Jumat, 10 April 2020, pemerintah mulai memberlakukan PSBB atau Pembatasan Sosial Berskala Besar.
Kebijakan ini tentu tak dibuat tanpa adanya alasan yang jelas. Dilansir dari detik.com, nyatanya terdapat fungsi PSBB yang diperkirakan mampu memberikan dampak yang cukup signifikan terhadap penyebaran Covid-19 di Indonesia.

Achmad Yurianto selaku juru bicara pemerintah mengungkapkan bahwa terdapat banyak sekali fungsi PSBB yang akan kita dapatkan sebagai masyarakat, diantaranya seperti mencegah terjadinya perkumpulan orang, baik dalam jumlah kecil hingga jumlah besar, dan menekan penyebaran virus corona itu sendiri di kalangan masyarakat.

Dengan adanya PSBB, diharapkan hal ini mampu melindungi orang-orang dari penularan Covid-19 hingga kasus terakhir. Namun, tentu saja tidak ada kebijakan yang berhasil tanpa adanya kerjasama dari masyarakatnya itu sendiri.

\section{Desentralisasi Pemerintah Pusat Kepada Pemerintah Daerah dalam Pelaksanaan Pembatasan Sosial Bersekala Besar}

Adanya PP mengenai PSBB memberikan kesempatan pada daerah untuk melakukan berbagai pertimbangan (Pasal 2) dan kemudian mengajukan PSBB kepada Menteri Kesehatan. Pemberlakuan dan penerapan PSBB memang bersifat sentralistis. Meski demikian, bukan berarti menutup ruang kreatif daerah. Undang-Undang Nomor 23 tahun 2014 tentang Pemerintahan Daerah memberi cukup ruang bagi daerah dalam penanganan pandemi (sebagai bencana atau keadaan luar biasa). Daerah bisa membuat perda, mengubah APBD, dan melakukan penanggulangan serta penanganan bencana. Dalam kacamata desentralisasi, penetapan dan pemberlakuan PSBB masih membuka ruang improvisasi dan transformasi bagi 
daerah. ${ }^{13}$ Pemda yang berhadapan langsung dengan penderita (ODP atau PDP) dan masyarakat beserta segala keunikan permasalahan serta dampak turunannya tentu harus mengambil keputusan cepat dan tepat. Ruang desentralisasi bisa dimanfaatkan untuk memperkuat ketahanan daerah (sosial, ekonomi masyarakat dan pemerintah daerah) selama pemberlakuan dan penerapan PSBB.

Ketahanan daerah Merujuk UU Nomor 23/ 2014 Pasal 316, pemerintah daerah bisa memanfaatkan ruang desentralisasi sebagai daerah otonom. Eksekutif dan legislatif bisa melakukan perubahan Anggaran Pendapatan dan Belanda Daerah (APBD) karena keadaan darurat dan/ atau luar biasa. Terkait pendanaan, daerah bisa mengakses penggunaan dana darurat dengan mengusulkannya kepada Mendagri (sesuai Pasal 296). Selain itu, DPRD atau kepala daerah dapat mengajukan rancangan perda di luar program pembentukan perda. Alasan mengatasi keadaan luar biasa, keadaaan konflik, atau bencana alam sesuai bunyi Pasal 239 bisa menjadi fondasinya. Selain itu, provinsi/kabupaten/kota memiliki kewenangan atas urusan penanggulangan dan penanganan bencana kabupaten/kota dan lintas daerah (lampiran UU). Tak hanya melakukan legislasi dan penganggaran, pemerintah daerah bisa memanfaatkan ruang desentralisasi lainnya. Daerah dapat mengembangkan program atau kegiatan berorientasi pada upaya membangun ketahanan sosial, ekonomi, kesehatan, dan pangan saat PSBB diterapkan.

Masing-masing pemerintah daerah bisa mengembangkan desain purwarupa (prototipe) ketahanan sosial, ekonomi, kesehatan, dan pangan berbasis empati di level masyarakat atau pemerintahan

${ }^{13}$ Yuliana, Corona Virus Diseases (Covid19); SEbuah Tinjauan Literatur, JUrnal Wellness terendah. Bekerja sama dengan perguruan tinggi, organisasi kemasyarakatan, dan dunia usaha, pemda bisa mendesain dan menguji purwarupa tersebut. Praktik desain purwarupa bisa dilakukan pada beberapa wilayah terkecil (kelurahan/desa). Kegiatan ini bisa dilakukan dalam 1-3 hari hingga purwarupa bisa diuji coba.

Selain pengembangan desain purwarupa berbasis wilayah, terutama pemerintah kabupaten/kota, bisa mengembangkan purwarupa berbasis bidang/isu untuk mengatasi masalah yang relatif sama dan dihadapi mayoritas masyarakat apabila PSBB diterapkan. Misalnya, purwarupa ketahanan UMKM, purwarupa ketahanan sosial-keagamaan, purwarupa ketahanan pertanian, purwarupa ketahanan pangan. Pengembangan purwarupa bisa dilakukan di spot-spot isu/bidang terdampak, seperti pasar, sentra UMKM, tempat ibadah, kelompok tani, karang taruna, dan lainnya. Kemudian, jika diperlukan, pemda bisa membandingkan antara purwarupa ketahanan masyarakat berbasis wilayah dan berbasis bidang/isu. Empat indikator yaitu efisiensi, efektivitas, keekonomisan, dan kemanfaatan publik, bisa digunakan untuk menilai inisiatif-inisiatif ini.

Dengan demikian, pemda bisa memilih atau menggabungkan secara akuntabel pengembangan dan implementasi purwarupa-purwarupa tersebut. Untuk pengembangan purwarupa ketahanan masyarakat berbasis bidang/isu, dinas/organisasi perangkat daerah (OPD) terkait bisa menginisiasi dan terlibat langsung pada spot-spot isu. Sementara, dalam mendesain purwarupa berbasis wilayah, OPD berbasis wilayah (kelurahan dan kecamatan) bisa terlibat langsung agar purwarupa bisa diterapkan langsung di

And Healthy Magazine, Volume 2, Nomor 1, Februari, Taun 2020, hlm. 187-192. 
masyarakat. Tujuannya, meningkatkan ketahanan sosial, ekonomi, kesehatan, dan pangan pada masa penerapan PSBB di wilayah yang dinilai paling rawan/terdampak negatif penerapan PSBB. Sebagai langkah awal, pemda bisa mengimplementasikan purwarupa tersebut pada skala kecil. Jika berhasil, pemda bisa melakukan scalling up hingga level yang lebih luas di seluruh wilayah. Opsi lainnya, purwarupa dapat diterapkan pada wilayah penerapan PSBB sesuai hasil kajian efek negatif penerapan PSSB pada wilayah atau spot bidang paling terdampak.

Bagi pemerintah provinsi, efekefek negatif PSBB bersifat lintas daerah bisa menjadi perhatian. Provinsi bisa berkolaborasi dengan pemerintah daerah yang terkena efek lintas daerah PSBB untuk membangun purwarupa ketahanan lintas daerah. Provinsi juga bisa mengajak perguruan tinggi, organisasi dunia usaha, dan ormas pada tingkat provinsi untuk membantu membangun purwarupa itu. Tafsir baru Wabah Covid19 yang tidak mengenal batas negara dan daerah telah memberikan pelajaran bagi kebijakan dan praktik desentralisasi (otonomi daerah). Desentralisasi harus ditempatkan pada paradigma yang lebih tepat dalam konsepsi negara kesatuan. Negara mewadahi kebutuhan dan permintaan masyarakat yang berbeda pada tiap daerah. Selain itu, barometer negara kesatuan bukan lagi bertumpu pada kontrol pusat, melainkan pemberdayaan daerah dalam mengatasi ancaman ketahanan karena pandemi. Bingkai smart policy lebih tepat guna membuka ruang gerak kreativitas dan inovasi daerah dalam menangani wabah.

Pemerintah mengedepankan prinsip negara sebagai pemecah masalah. Pemerintah meminimalisir penggunaan kesalahan daerah sebagai legitimasi untuk melakukan resentralisasi. Pemerintah sebaiknya memfasilitasi transfer praktik-praktik terbaik daerah dalam penanganan pandemi. Untuk menghadapi wabah, pemerintah perlu membuat regulasi yang mendorong dialog dan negosiasi antara pemerintah dan daerah. Dengan demikian, pandemi bisa ditangani lebih efektif. Pertimbangannya, daerah memiliki kebutuhan khusus yang tidak selamanya terakomodasi dalam kebijakan nasional. Kebijakan pemerintah sebaiknya mampu mendorong lahirnya inovasi-inovasi daerah dalam penanganan wabah. Inovasi berguna dalam menyiasati keterbatasan dan perbedaan konteks tiap daerah. Prinsipnya, desentralisasi membutuhkan insentif positif, bukan hukuman. Oleh karena itu, kebijakan pusat yang berbasis insentif lebih ditunggu dalam menangani dan meminimalisir dampak pandemi.

\section{PENUTUP}

Pandemi Covid-19 yang berlangsung hampir di seluruh negara di dunia. Seiring dengan semakin gencarnya strategi pemerintah dalam menanggulangi penyebaran virus corona Covid-19 yang masih mewabah hingga saat ini pemerintah mulai memberlakukan Pembatasan Sosial Berskala Besar (PSBB) dengan telah ditandatangani Peraturan Pemerintah (PP) Nomor 21 Tahun 2020 tentang PSBB yang dianggap mampu mempercepat penanggulangan sekaligus mencegah penyebaran corona yang semakin meluas di Indonesia. Dalam Pasal 1 dijelaskan bahwa Pembatasan Sosial Berskala Besar merupakan pembatasan kegiatan tertentu dalam suatu wilayah yang diduga terinfeksi Coronavirus Disease 2019 (Covid-19).

PSBB sendiri merupakan salah satu strategi pemerintah dalam mencegah kemungkinan penyebaran virus corona, yang mana juga telah tertuang di dalam aturan PMK Nomor 9 Tahun 2020. 
Tertulis pula di dalam aturan PMK Nomor 9 Tahun 2020 Pasal 2, bahwa untuk dapat ditetapkan sebagai PSBB maka suatu wilayah provinsi/ kabupaten/ kota harus memenuhi dua kriteria. Pertama, yaitu jumlah kasus atau kematian akibat penyakit meningkat dan menyebar secara signifikan secara cepat ke beberapa wilayah. Adanya PP mengenai PSBB memberikan kesempatan pada daerah untuk melakukan berbagai pertimbangan (Pasal 2) dan kemudian mengajukan PSBB kepada Menteri Kesehatan. Pemberlakuan dan penerapan PSBB memang bersifat sentralistis. Meski demikian, bukan berarti menutup ruang kreatif daerah. Undang-Undang Nomor 23 tahun 2014 tentang Pemerintahan Daerah memberi cukup ruang bagi daerah dalam penanganan pandemi (sebagai bencana atau keadaan luar biasa). Daerah bisa membuat perda, mengubah APBD, dan melakukan penanggulangan serta penanganan bencana.

\section{DAFTAR PUSTAKA}

El-Muthtaj, Majda, Hak Asasi Manusia dalam Konstitusi Indonesia, Jakarta: Kencana Prenada Media Group, 2009, hlm. 45.

World Health Organization Press Conference

(https://www.who.int/emergenc ies/diseases/novel-

coronavirus2019?gclid $=\mathrm{CjwKC}$ Ajwq832BRA5EiwACvCWsbp LiaNmFMJRaG905w1XqiiOfpg UkZ_PMEfS_WxqpaEW93J3snu8xoClXcQAv D_BwE) Diakses pada minggu tanggal 31 Mei 2020 pukul 20.52 WIB

Keputusan Presiden RI Nomor 12 Tahun 2020 tentang Penetapan bencana non alam penyebaran Covid-19 sebagai bencana nasional https://jdih.setneg.go.id/viewpdf
peraturan/P18857/Keppres\%20

Nomor\%2012\%20Tahun\%2020

20 Diakses pada minggu tanggal

31 Mei 2020 pukul 20.58 WIB

Data Sebaran Situasi virus Covid-19 di Indonesia https://covid19.go.id/ Diakses minggu tanggal $31 \mathrm{Mei}$ 2020 pada 21.01 WIB

Data Sebaran Situasi virus Covid-19 di Indonesia https://covid19.go.id/ Diakses minggu tanggal $31 \mathrm{Mei}$ 2020 pada 21.01 WIB

Budi Andriyansayah, Hak Atas Kesehatan dan Perlindungannya, Jurnal Ilmu Hukum, Volume. 1, Nomor.2, September, 2017, hlm. 123-135.

Muladi, Sumbang Saran Peruabahan UUD 1945, Jakarta: Yayasan Habibie Center, 2004, hlm. 16.

Mile Parwanto, Virus Corona (2019nCoV) Penyebab Covid-19, Jurnal Biomedika dan Kesehatan, Volume.3, Nomor,1, Maret, 2020, hlm. 1-2.

Eman Supriatna, Wabah Corona Virus Diasea Covid 19 dalam Pandangan Islam, SALAM: JUrnal Sosial dan BUdaya Syar'I, Volume.7, NOmor.6 Tahun 2020, hlm. 555-567, DOI:

10.15408/sjsbs.v7i6.15247

Silpa Hnoatubun, Dampak Covid-19 Tergadap Perekonomian Indonesia, Journal of Education, Psychology and Counseling, Volume 2, Nomor 1, Tahun 2020, hlm. 146-153.

Yuliana, Corona Virus Diseases (Covid19); SEbuah Tinjauan Literatur, JUrnal Wellness And Healthy Magazine, Volume 2, Nomor 1, Februari, Taun 2020, hlm. 187192. 